\title{
Response of Cellulase Activity in pH-Controlled Cultures of the Filamentous Fungus Acremonium cellulolyticus
}

\author{
Joni Prasetyo $\cdot$ Shyuuhei Sumita $\cdot$ Naoyuki Okuda $・$ \\ Enoch Y. Park
}

Received: 24 April 2009 / Accepted: 14 October 2009 /

Published online: 1 November 2009

(C) The Author(s) 2009. This article is published with open access at Springerlink.com

\begin{abstract}
Cellulase production was investigated in $\mathrm{pH}$-controlled cultures of Acremonium cellulolyticus. The response to culture $\mathrm{pH}$ was investigated for three cellulolytic enzymes, carbomethyl cellulase (CMCase), avicelase, and $\beta$-glucosidase. Avicelase and $\beta$-glucosidase showed similar profiles, with maximum activity in cultures at $\mathrm{pH} 5.5-6$. The CMCase activity was highest in a $\mathrm{pH} 4$ culture. At an acidic $\mathrm{pH}$, the ratios of CMCase and avicelase activity to cellulase activity defined by filter paper unit were high, but at a neutral $\mathrm{pH}$, the $\beta$-glucosidase ratio was high. The $\mathrm{pH} 6.0$ culture showed the highest cellulase activity within the range of $\mathrm{pH} 3.5-6.5$ cultures. The saccharification activity from $A$. cellulolyticus was compared to those of the cellulolytic enzymes from other species. The $A$. cellulolyticus culture broth had a saccharification yield comparable to those of the Trichoderma enzymes GC220 and Cellulosin T2, under conditions with the same cellulase activity. The saccharification yields from Solka floc, Avicel, and waste paper, measured as the percent of released reducing sugar to dried substrate, were greater than $80 \%$ after $96 \mathrm{~h}$ of reaction. The yields were $16 \%$ from carboxymethylcellulose and $26 \%$ from wood chip refiner. Thus, the A. cellulolyticus enzymes were suitable for converting cellulolytic biomass to reducing sugars for biomass ethanol production. This study is a step toward the establishment of an efficient system to reutilize cellulolytic biomass.
\end{abstract}

J. Prasetyo E. Y. Park $(\bowtie)$

Laboratory of Biotechnology, Integrated Bioscience Section, Graduate School of Science and Technology, Shizuoka University, 836 Ohya, Shizuoka 422-8529, Japan

e-mail: acypark@ipc.shizuoka.ac.jp

S. Sumita

Department of Applied Biological Chemistry, Faculty of Agriculture, Shizuoka University, 836 Ohya, Shizuoka 422-8529, Japan

N. Okuda

Sugar \& Bio Technology Department, Tsukishima Kikai Co., Ltd., 17-15 Tsukuda, 2-Chome, Chuo-ku, Tokyo 104-0051, Japan 
Keywords Cellulase $\cdot$ Acremonium cellulolyticus $\cdot$ Biomass $\cdot$ Saccharification Lignocellulose

\section{Introduction}

Biomass, which is a lignocellulosic material from sources such as agricultural waste and woody materials, represents an abundant renewable energy source. Many researchers have focused on producing value-added materials from biomass, and new technologies have been developed [1-3]. However, before biomass can be used, pretreatment is necessary to break the lignocellulose down into its three major polymeric constituents: cellulose, hemicelluloses, and lignin. Different pretreatment methods such as steam explosion [4, 5], wet oxidation [6,7], and microwaves [8] have been proposed for lignocellulose fractionation, in which most of the hemicellulose and lignin degradation products are dissolved, and the cellulose is recovered in the solid fraction. The cellulose is either used for paper production or is further hydrolyzed by cellulolytic enzymes or acids to readily usable carbon and energy in the fermentation process. Although costefficient acids can be used as hydrolysis agents, they are not environmentally friendly because they require high temperatures and generate acidic waste. Producing costefficient cellulolytic enzymes from microorganisms is thus an important focus of research. However, the current technologies have not been adopted yet because of the high cost of commercial enzymes.

Many well-studied microorganisms produce cellulolytic enzymes; for example, the genus Trichoderma produces cellulolytic enzymes with relatively high enzymatic activity. However, the Trichoderma enzymes alone cannot effectively hydrolyze cellulose biomass, because of their enzymatic composition. The saccharification activity of enzymes is particularly important for producing reducing sugars, especially glucose, from cellulolytic biomass. This ability depends on the composition of the enzymes, particularly the crystalline cellulose-hydrolyzing enzyme and $\beta$-glucosidase.

Acremonium cellulolyticus, which was isolated in 1987 and subsequently improved to increase performance, produces both enzymes, in addition to CMCase and small amounts of xylanase, $\beta$-1,3-glucanase, and amylase [9]. Twelve distinct endo-cellulases and four $\beta$-glucosidases have been purified from $A$. cellulolyticus. One of the endo-cellulases possesses a potent ability to produce glucose from cellobiose [10]. Thus, the $A$. cellulolyticus enzymatic activity effectively hydrolyzes cellulolytic biomass. Indeed, the commercial enzymes produced from $A$. cellulolyticus have high hydrolytic activity against cellulolytic wastes, as compared to the Trichoderma enzymes [11]. In spite of this performance, few studies on the use of A. cellulolyticus for cellulase production have been reported [9-14], although the results have demonstrated its unique enzyme composition and relatively high cellulase activity [9]. Nonetheless, the activity obtained in the reported studies was insufficient for the hydrolysis of industrial amounts of cellulolytic biomass.

The aim of this research was to achieve the efficient, industrial-scale production of cellulolytic enzymes using the filamentous fungus Ferm P-18508 A. cellulolyticus C-1, which is a hyperproducing mutant of the original strain, A. cellulolyticus Y-94. This paper focuses on the response to the culture $\mathrm{pH}$ of the CMCase, $\beta$-glucosidase, and avicelase enzymes of $A$. cellulolyticus. The culture broths were subjected to a saccharification test to assess the enzymatic performance. 


\section{Materials and Methods}

\section{Strains and Culture Media}

Ferm P-18508 A. cellulolyticus $\mathrm{C}-1$ was seeded on potato dextrose agar slants, incubated at $30{ }^{\circ} \mathrm{C}$ for $3-5$ days until colonies grew, and then stored at $4{ }^{\circ} \mathrm{C}$. The colonies were colored brown to reddish-brown and had short white hyphae and no spores.

The preculture medium contained $40 \mathrm{~g} / 1$ cellulose powder, $24 \mathrm{~g} / 1 \mathrm{KH}_{2} \mathrm{PO}_{4}, 10 \mathrm{~g} / 1 \mathrm{corn}$ steep liquor, $1 \mathrm{~g} / \mathrm{l}$ Tween $80,5 \mathrm{~g} / 1\left(\mathrm{NH}_{4}\right)_{2} \mathrm{SO}_{4}, 4.7 \mathrm{~g} / 1$ potassium tartrate, $1.2 \mathrm{~g} / \mathrm{l}$ $\mathrm{MgSO}_{4} \cdot 7 \mathrm{H}_{2} \mathrm{O}, 0.01 \mathrm{~g} / 1 \mathrm{ZnSO}_{4} \cdot 7 \mathrm{H}_{2} \mathrm{O}, 0.01 \mathrm{~g} / 1 \mathrm{MnSO}_{4} \cdot 6 \mathrm{H}_{2} \mathrm{O}, 0.01 \mathrm{~g} / 1 \mathrm{CuSO}_{4} \cdot 7 \mathrm{H}_{2} \mathrm{O}$, and 2 g/l urea, pH 4.0 [15]. Solka floc (CAS no. 9004-34-6, Fibers Sales \& Development Co. Urbana, $\mathrm{OH}, \mathrm{USA}$ ) was used as the cellulose powder. The cellulase production medium contained $50 \mathrm{~g} / 1$ cellulose powder, $1 \mathrm{~g} / 1 \mathrm{KH}_{2} \mathrm{PO}_{4}, 1 \mathrm{~g} / 1$ Tween $80,5 \mathrm{~g} / 1\left(\mathrm{NH}_{4}\right)_{2} \mathrm{SO}_{4}, 4.7 \mathrm{~g} / 1$ potassium tartrate, $1.2 \mathrm{~g} / 1 \mathrm{MgSO}_{4} \cdot 7 \mathrm{H}_{2} \mathrm{O}, 0.01 \mathrm{~g} / 1 \mathrm{ZnSO}_{4} \cdot 7 \mathrm{H}_{2} \mathrm{O}, 0.01 \mathrm{~g} / 1 \mathrm{MnSO}_{4} \cdot 6 \mathrm{H}_{2} \mathrm{O}$, $0.01 \mathrm{~g} / 1 \mathrm{CuSO}_{4} \cdot 7 \mathrm{H}_{2} \mathrm{O}$, and $4 \mathrm{~g} / 1$ urea.

For flask cultures, one colony was inoculated into an L-shaped test tube containing $5 \mathrm{ml}$ of preculture medium. The preculture was incubated for $65 \mathrm{~h}$ at $30{ }^{\circ} \mathrm{C}$ at 90 shakes per minute (spm) in a reciprocal shaker (SJ-10R, TAITEC Co., Ltd., Japan). For cellulase production in flasks, a $2.5 \mathrm{ml}$ portion of the preculture was inoculated into a $500-\mathrm{ml}$ Erlenmeyer flask containing $50 \mathrm{ml}$ of production medium. The cultures were incubated for 5-8 days at $30{ }^{\circ} \mathrm{C}$ at $220 \mathrm{rpm}$ in a rotary shaker (Takasaki Sci. Instru. Co., Japan).

\section{pH-Controlled Cellulase Production}

A 3-1 bioreactor (MD-400, Marubishi, Co., Ltd., Japan) with a 1.51 working volume was used for $\mathrm{pH}$-controlled cellulase production. Distilled water was used for all components of the production medium, and the system was sterilized at $121{ }^{\circ} \mathrm{C}$ for $20 \mathrm{~min}$. Solka floc and Tween 80 were mixed in $500 \mathrm{ml}$ of distilled water and sterilized separately to prevent blockage of the bioreactor air nozzles and to avoid excess bubble formation in the medium. The appropriate amount of urea, in $50 \mathrm{ml}$ of distilled water, was filtered with a $0.45 \mu \mathrm{m}$ filter. The sterilized Solka floc, Tween 80 , and urea were added to the bioreactor before inoculation.

Two colonies were inoculated into 500-ml Erlenmeyer flasks containing $50 \mathrm{ml}$ of preculture medium and were cultured at $30{ }^{\circ} \mathrm{C}, 220 \mathrm{rpm}$ for $96 \mathrm{~h}$. An inoculum of $150 \mathrm{ml}$ was added to the bioreactor and was cultured at $30{ }^{\circ} \mathrm{C}$. The $\mathrm{pH}$ was controlled at $3.5,4.0$, $4.5,5.0,5.5,6.0$, or 6.5 with $5 \% \mathrm{NH}_{4} \mathrm{OH}$ and $2 \mathrm{~N} \mathrm{H}_{2} \mathrm{SO}_{4}$. Air was supplied at 1 volume of air per volume of medium per minute, with an agitation rate of $600 \mathrm{rpm}$. An anti-foam agent (Silicone 72, KM-70, Shin-Etsu Chemical Co. Ltd. Japan) was added in small amounts as needed. Each experiment was carried out in triplicate; data are presented as averages.

\section{Saccharification Yields from A. cellulolyticus Culture Broth}

To investigate the enzymatic performance in A. cellulolyticus culture broth, saccharification experiments were conducted on culture supernatants. Two commercial enzymes were used for comparison: GC 220 from Trichoderma reesei (Genencor International Inc., CA, USA) and Cellulosin T2 from Trichoderma viride (HBI Enzymes Inc., Osaka, Japan). The filter paper unit (FPU) activities of GC 220 and Cellulosin T2 were 443.3 and 0.9 FPU/mg of enzyme, respectively, and were adjusted to $15 \mathrm{FPU} / \mathrm{g}$-dry biomass before use. Solka floc, 
Avicel, carboxymethylcellulose (CMC), waste office paper, and waste wood chip refiner were used to evaluate the saccharification efficiency. Waste paper was cut with a standard office shredder into $2 \mathrm{~mm} \times 1.5 \mathrm{~cm}$ rectangles and was used for enzymatic hydrolysis without further pretreatment [16]. Waste wood chips were broken down to 12-mm mesh particles and were pre-treated with $2 \%$ sulfuric acid at $170{ }^{\circ} \mathrm{C}$ for $10 \mathrm{~min}$. Chips were ground into a powder using a Recycle Refiner (Aikawa Iron Works Co., Shizuoka, Japan).

Sterilized flasks containing $50 \mathrm{ml}$ of $0.1 \mathrm{M}$ acetate buffer $(\mathrm{pH} 4.5)$ and $1.5 \mathrm{~g}$ dried substrate were incubated at $45{ }^{\circ} \mathrm{C}$ for $10 \mathrm{~min}$. Hydrolysis of the substrate was initiated by the addition of commercial cellulase powders or A. cellulolyticus culture broth. Reactions were conducted in 500-ml Erlenmeyer flasks using a reciprocal shaker at $110 \mathrm{spm}$ for $96 \mathrm{~h}$ at $45{ }^{\circ} \mathrm{C}$. Samples were boiled to terminate the reactions, and the reaction mixtures were centrifuged at 10,000 rpm for $5 \mathrm{~min}$. Reducing sugars and glucose concentrations were measured in the supernatants. The saccharification yield (\%) of substrates to reducing sugar $(x)$ was calculated as:

$$
x=\frac{\text { Reducing sugar concentration }(\mathrm{g} / \mathrm{l}) \times \text { Volume of hydrolysate }(\mathrm{l})}{\text { Dry weight of biomass }(\mathrm{g}) \times \text { Cellulose content in biomass }(\%)} \times 100
$$

where the cellulose contents in office paper and wood chips were $80.3 \%$ and $49.9 \%$, respectively $[17,18]$.

\section{Analytical Methods}

Total cellulase activity was determined using the IUPAC standard procedure with Whatman no. 1 filter paper $[19,20]$ and is expressed in FPU. Cellulase components were analyzed as follows. Avicel (1\% w/v, Sigma-Aldrich Chem. $\mathrm{GmbH})$ in acetate buffer (50 mM, pH 5.5) and the diluted enzyme solution were mixed in equal volumes and were reacted at $30{ }^{\circ} \mathrm{C}$ for 120 min with shaking (160 spm), with sampling every $15 \mathrm{~min}$. A $180 \mu \mathrm{l}$ aliquot of CMS $(1 \% w / v$, Sigma-Aldrich Chem.) was mixed with $20 \mu$ of diluted enzyme solution in acetate buffer $(50 \mathrm{mM}, \mathrm{pH} 5.5)$ and was reacted at $40{ }^{\circ} \mathrm{C}$ for 15 min with sampling every $3 \mathrm{~min}$. The released reduced sugars were analyzed using the Somogyi-Nelson method [21]. One unit of enzyme activity was defined as the amount required to produce $1 \mu \mathrm{mol}$ of reducing sugars in $1 \mathrm{~min}$. The $\beta$-glucosidase activity was measured using glucose $\beta$-para-nitrophenyl $(\mathrm{Glc} \beta-\mathrm{pNP})$ as substrate. Aliquots $(25 \mu \mathrm{l})$ of Glc $\beta$-pNP $(10 \mathrm{mM})$ and the diluted enzyme solution were mixed in acetate buffer $(50 \mathrm{mM}, \mathrm{pH} 5.5)$ and then reacted at $40{ }^{\circ} \mathrm{C}$ for $10 \mathrm{~min}$. Samples were obtained every $2 \mathrm{~min}$. The reaction was stopped with $190 \mu \mathrm{l}$ of $\mathrm{Na}_{2} \mathrm{CO}_{3}(1 \mathrm{M})$, and the absorbance at $405 \mathrm{~nm}$ was measured. One unit of enzyme activity was defined as $1 \mu \mathrm{mol}$ of pNP released per $1 \mathrm{~min}$.

Due to the difficulty of separating the mycelium from the medium, the cell weight was measured using the inner nucleic acid (INA) method, and the dry cell weight (DCW) was calculated using the equation, DCW $(\mathrm{g} / \mathrm{l})=\mathrm{INA}(\mathrm{g} / \mathrm{l}) \times 16.565$.

Supernatant protein concentrations were determined with a Bio-Rad Protein Assay kit (Bio-Rad Lab., USA). The concentration of reducing sugars in the medium was analyzed using the dinitrosalicylic acid method [22] and HPLC (PU-980, JASCO, Co. Ltd., Japan) with Shim-pack CLC-NH ${ }_{2}$ columns (Shimadzu Co., Kyoto, Japan) and a mobile phase of a $75 \%$ acetonitrile solution at a flow rate of $2 \mathrm{ml} / \mathrm{min}$. Detection was accomplished with a refractive index detector (RI-930, JASCO, Co. Ltd., Tokyo, Japan). The glucose concentration was measured using a glucose kit (Wako Co. Ltd., Japan). 


\section{Results}

Effect of Phosphate on Cellulase Production from A. cellulolyticus C1

When A. cellulolyticus was cultured in medium with an initial monophotassium phosphate concentration of $24 \mathrm{~g} / \mathrm{l}$, only $0.8 \mathrm{~g} / \mathrm{l}$ phosphate was consumed (data not shown). This indicated that approximately $1 \mathrm{~g} / 1$ phosphate is sufficient for an $A$. cellulolyticus culture. This was confirmed with cultures containing initial phosphate concentrations of 24 and 1 g/l (Fig. 1). When the initial phosphate concentration was $1 \mathrm{~g} / \mathrm{l}$, the $\mathrm{pH}$ increased to 8 after $36 \mathrm{~h}$ of culture, and the cellulase activity was below $0.5 \mathrm{FPU} / \mathrm{ml}$. However, at $24 \mathrm{~g} / \mathrm{l}$ initial phosphate, the $\mathrm{pH}$ was maintained at 5.5-6.0 during cellulase production, and the cellulase activity increased with the culture time, reaching $13.2 \mathrm{FPU} / \mathrm{ml}$ at $84 \mathrm{~h}$. The dry cell weight was 2.5 times higher than that obtained with $1 \mathrm{~g} / \mathrm{l}$ initial phosphate. This indicates that the phosphate in the medium played an important role as a buffer in culture $\mathrm{pH}$ maintenance, suggesting that $\mathrm{pH}$ control is required for cellulase production in medium with weak buffering capacity.

\section{Cellulase Production in $\mathrm{pH}-$ Controlled Cultures}

The culture $\mathrm{pH}$ was controlled from 3.5 to 6.5 , using sulfuric acid and ammonium water. The cellulase activity was highest in the $\mathrm{pH} 6.0$ culture $(13.8 \mathrm{FPU} / \mathrm{ml}$; Fig. 2a). At pH values of 4.0 and 5.5 , the cellulase activity was $10.5 \mathrm{FPU} / \mathrm{ml}$. In the $\mathrm{pH} 4.5$-controlled culture, the cellulase activity was initially similar to those of the $\mathrm{pH} 4.0$ - and 5.5-controlled cultures, but decreased and ended at $7 \mathrm{FPU} / \mathrm{ml}$. In the $\mathrm{pH}$ 6.5- and 3.5-controlled cultures, the cellulase production was significantly lower than those in other cultures. The dry cell

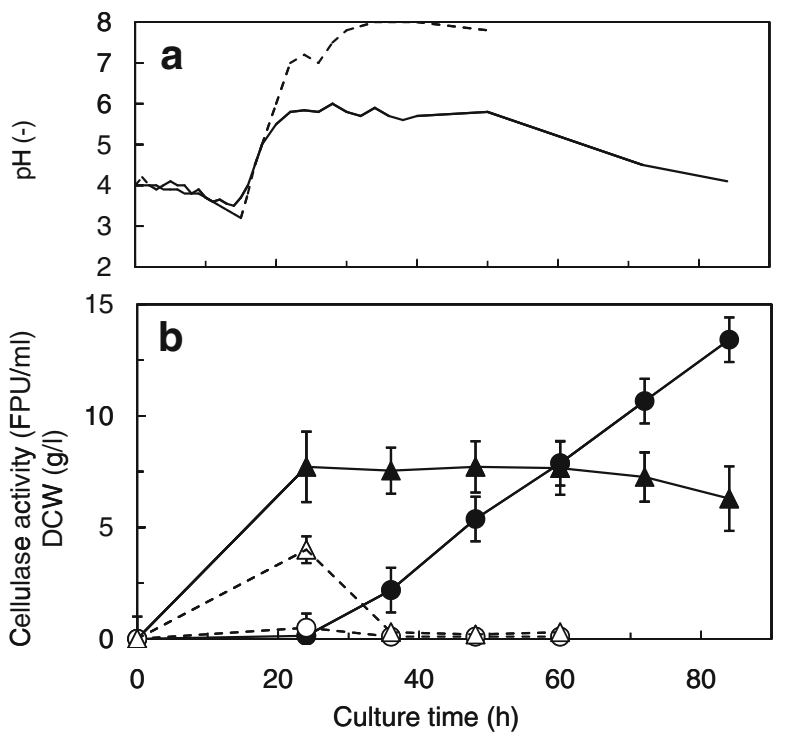

Fig. 1 pH profiles (a) and cellulase activity and dry cell weight (b) in batch cultures of A. cellulolyticus $\mathrm{C} 1$ in a 3-1 bioreactor. Dotted and solid lines in a denote the $\mathrm{pH}$ values of cultures with initial monopotassium phosphate concentrations of 1 and $24 \mathrm{~g} / \mathrm{l}$, respectively. Closed circles and closed triangles in $\mathbf{b}$ indicate cellulase activity and dry cell weight, respectively, when the initial monopotassium phosphate concentration was $24 \mathrm{~g} / \mathrm{l}$; open circles and open triangles in b indicate cellulase activity and dry cell weight, respectively, when the initial monopotassium phosphate concentration was $1 \mathrm{~g} / \mathrm{l}$ 
Fig. 2 Time courses of cellulase activity (a), dry cell weight (b), and protein concentration (c) in cultures with $\mathrm{pH}$-controlled at 3.5 (open circles), 4.0 (closed circles), 4.5 (open rhombuses), 5.0 (closed triangles), 5.5 (open triangles), 6.0 (closed squares), and 6.5 (open squares). $\mathbf{d} \mathrm{pH}$ response of the cellulase production rate (closed circles) and the specific cellulase activity (open circles). The cellulase production rate and the specific cellulase activity were calculated from the data shown in a and $\mathbf{c}$
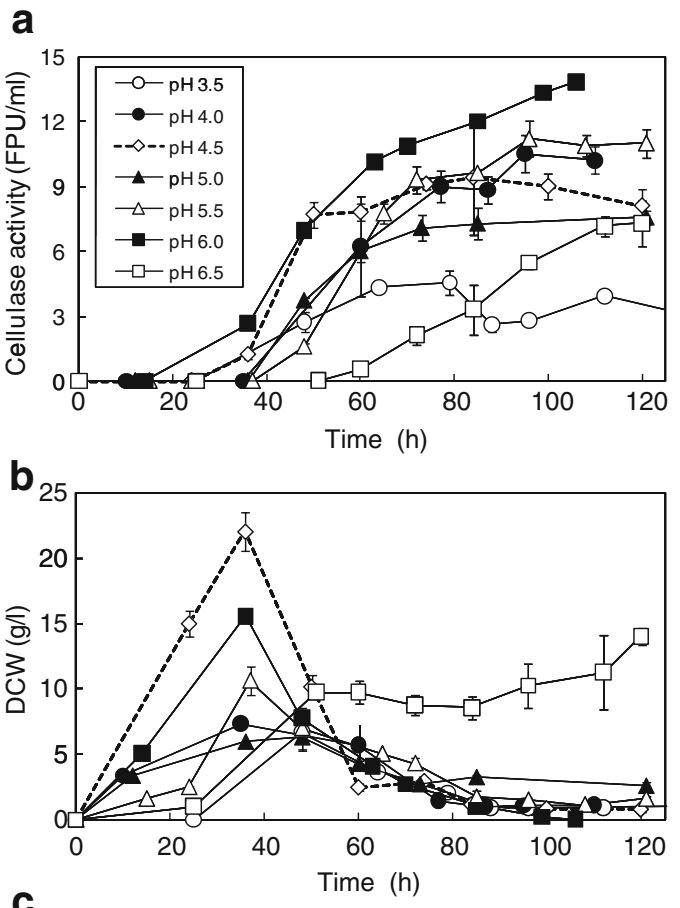

C
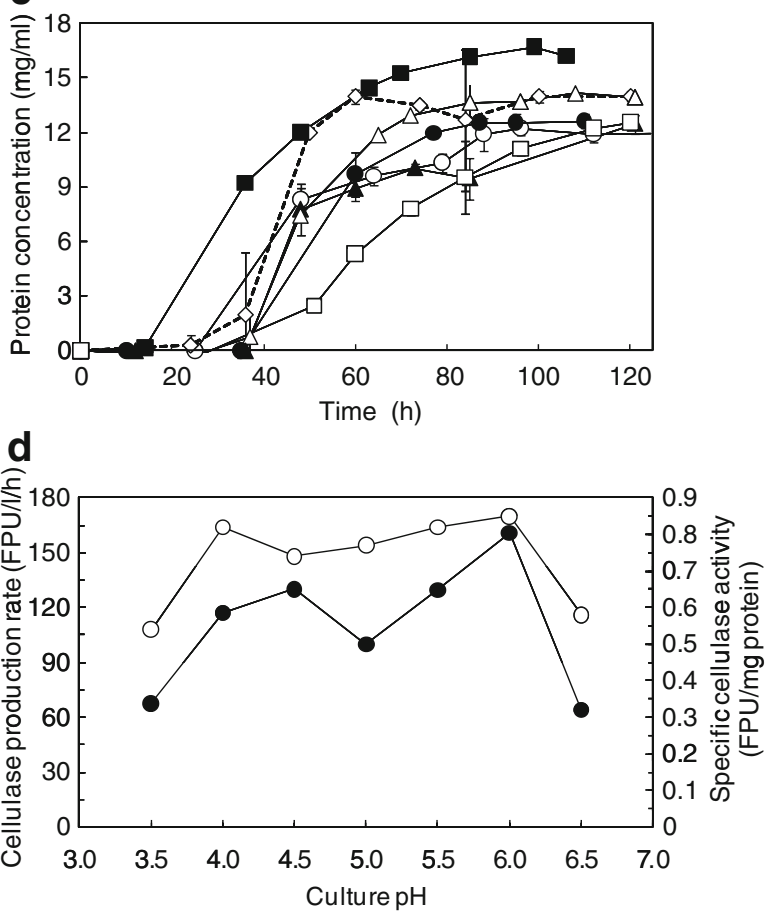
weight increased until $36 \mathrm{~h}$, but then decreased in all except the $\mathrm{pH}$ 6.5-controlled culture (Fig. 2b). At an acidic $\mathrm{pH}$ ( $\mathrm{pH} 4.5$ only), the dry cell weight reached $22.5 \mathrm{~g} / 1$, before decreasing sharply.

The protein concentration profiles (Fig. 2c) were similar to those of the cellulase activity. The maximum specific cellulase activities based on the extracellular protein concentration were in the range of $0.75-0.85 \mathrm{FPU} / \mathrm{mg}$ protein for all except the $\mathrm{pH} 3.5$ - and 6.5controlled cultures (Fig. 2d). The highest production rate, $160.9 \mathrm{FPU} / \mathrm{l} / \mathrm{h}$, was achieved in the $\mathrm{pH}$ 6.0-controlled culture (Fig. 2d). The values of the $\mathrm{pH} 4.0$ - and 4.5-controlled cultures were 117 and $130 \mathrm{FPU} / \mathrm{l} / \mathrm{h}$, respectively, which were higher than those of the other cultures. Interestingly, the production rate of the $\mathrm{pH}$ 5.0-controlled culture fell to $100 \mathrm{FPU} /$ $1 / \mathrm{h}$. When the culture $\mathrm{pH}$ was controlled between 3.5 and 6.5 , the cellulase production rate showed two peaks, at $\mathrm{pH} 4.0-4.5$ and 6.0 (Fig. 2d). The traces of the $\mathrm{pH}$ responses of the specific cellulase activity and the cellulase production rate were found to be M-shaped, which is the first such finding for cellulase production using A. cellulolyticus.

\section{Cellulase Activity in $\mathrm{pH}-$ Controlled Cultures}

The cellulase activity also showed two peaks, at $\mathrm{pH} 4.0-4.5$ and 6.0 (Fig. 3a). To investigate the cellulase response to culture $\mathrm{pH}$, three enzyme activities were analyzed. The CMCase activity was maximal in the $\mathrm{pH} 4.0$ - and 5.5-controlled cultures, but lowest in the $\mathrm{pH} 4.5$ culture (Fig. 3b). The avicelase activity showed two peaks in the $\mathrm{pH} 4.5$ - and 6.0controlled cultures (Fig. 3c). The $\beta$-glucosidase activity was maximal in the pH-5.5 and 6.0-controlled cultures and was low at the acidic $\mathrm{pH}$ and at $\mathrm{pH} 6.5$ (Fig. 3d). The first peak shown in the $\mathrm{pH} 4.0$ - and 4.5-controlled cultures (Fig. 3a) was due to the high CMCase activity; the second peak ( $\mathrm{pH}$ 6.0-controlled culture) was caused by the high activities of avicelase and $\beta$-glucosidase. In the $\mathrm{pH} 4.5$ - and 5.0-controlled cultures, either the CMCase or avicelase activity was low, along with the $\beta$-glucosidase. These results reflect the fact that the cellulase activity represents a combination of three enzymatic activities that are sensitive to the $\mathrm{pH}$ of the culture.

The effect of the culture $\mathrm{pH}$ on the ratios of each enzyme to the cellulase activity is significant (Fig. 3b-d). In the acidic pH-controlled cultures, the ratios of the avicelase and CMCase activities were higher than those of the neutral $\mathrm{pH}$-controlled cultures. On the other hand, the ratio of the $\beta$-glucosidase activity was higher at the neutral $\mathrm{pH}$ range than those in the acidic $\mathrm{pH}$ ranges. This result suggests that the saccharification yield is dependent upon the $\mathrm{pH}$ condition of the saccharification reaction.

\section{Saccharification by A. cellulolyticus Culture Supernatants}

The culture supernatant of A. cellulolyticus and two other commercial enzymes were applied to the hydrolysis of Solka floc, Avicel, CMC, waste paper, and waste wood refiner. The saccharification yields of Solka floc, Avicel, and waste paper were greater than $80 \%$ in a $96 \mathrm{~h}$ reaction (Fig. 4). The Trichoderma enzymes GC220 and Cellulosin T2 converted $46-50 \%$ and $33-40 \%$ of the substrate to reducing sugars, respectively. The saccharification yields from $\mathrm{CMC}$ and refiner were $8-26 \%$, using the three types of cellulase. The hydrolysis of wood chip refiner was similar among the three enzyme treatments; specifically, it was $26 \%$ in the culture supernatant of $A$. cellulolyticus, $17 \%$ in GC220, and $16 \%$ in T2 Cellulosin. Since most of the cellulose in wood chips is surrounded by lignin, it is difficult for enzymes to attack, which is one reason why the saccharification yields were lower than those from waste paper.

\section{㴡: Humana Press}


Fig. $3 \mathrm{pH}$ response of cellulase activity (a), CMCase and its ratio to cellulase (b), avicelase and its ratio to cellulase (c), and $\beta$-glucosidase and its ratio to cellulase (d). The enzyme activity (straight lines) and the ratio of each enzyme to cellulase (dotted lines) were analyzed at the end of each $\mathrm{pH}$-controlled culture
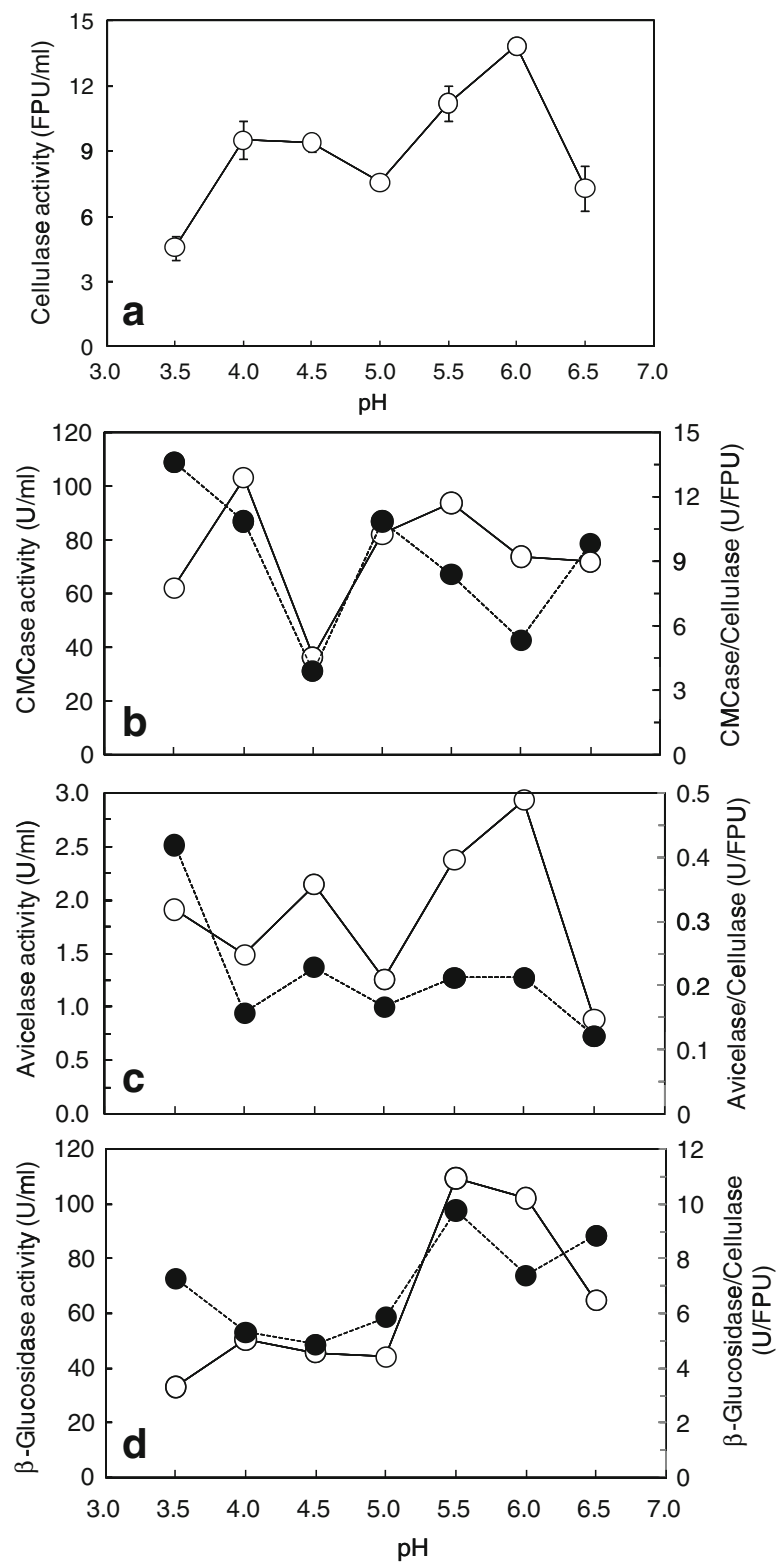

The glucose content in the reaction mixture of A. cellulolyticus was $83 \%$. The other $13 \%$ of reducing sugars were presumed to be xylose and cellobiose, based on previous research $[8,11]$. The culture supernatant of $A$. cellulolyticus produced large amounts of glucose, while the enzymes from Trichoderma gave a lower glucose ratio. This is consistent with reports from other research groups [13]. Since members of the Trichoderma genus generally produce relatively low levels of $\beta$-glucosidase, they do not convert cellulolytic biomass to glucose efficiently. Thus, it is important to have a high glucose concentration in the hydrolysis solution, since it is the only sugar that the microorganisms can easily 
Fig. 4 Comparison of the enzymatic performance using Solka floc, Avicel, CMC, waste paper, and waste wood chips refiner. Closed, open, and gray bars denote saccharification yields using culture solutions, GC220, and Cellulosin T2, respectively

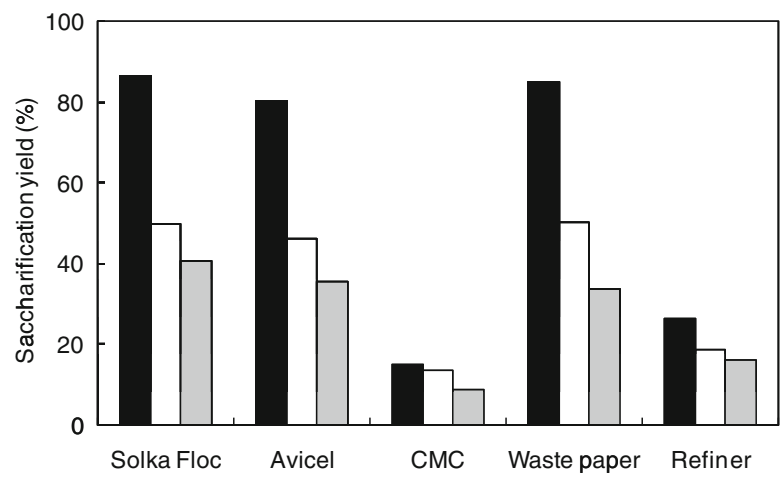

assimilate. The A. cellulolyticus supernatant had the highest saccharification yield and glucose content of all enzyme mixtures tested. This confirmed that the A. cellulolyticus enzymes have a remarkable ability to hydrolyze cellulolytic biomass.

\section{Discussion}

Cellulose-hydrolyzing enzymes, also called cellulolytic enzymes or simply cellulases, can play a crucial role in the environmentally friendly utilization of cellulolytic biomass. Most research on cellulase production has used cellulose powder or cellulolytic biomass as a carbon source, and the cellulase producer is usually Trichoderma sp. [22-25]. Using this organism, corn fiber [24], wheat straw [26], waste newspaper and sorbose, and manure [2729] have been used for cellulase production. Penicillium brasilianum [30] or Penicillium janthinellum [31] have also been reported as cellulase producers.

Yamanobe et al. [9] isolated A. cellulolyticus Y-94 and obtained 5.0 FPU/ml from cellulose powder, which represented remarkably efficient hydrolysis, and a relatively high FPU value. However, these cellulase activities are insufficient for the industrial hydrolysis of cellulolytic biomass. Therefore, to obtain higher cellulase activity, we improved the cell line and optimized the medium for the practical production of cellulase. The optimized medium was used for 501 scale-up experiments [15], which yielded cultures of Ferm P18508 A. cellulolyticus $\mathrm{C} 1$ that could produce $15.5 \mathrm{FPU} / \mathrm{ml}$ of cellulase activity in flask cultures, $17.42 \mathrm{FPU} / \mathrm{ml}$ in a $7-1$ bioreactor, and $13.08 \mathrm{FPU} / 1 \mathrm{ml}$ in a $50-1$ bioreactor.

A. cellulolyticus produces several cellulases and $\beta$-glucosidases [8]. Additionally, one of its endo-cellulase components effectively produces glucose from cellobiose [8]. In this study, CMCase, avicelase, and $\beta$-glucosidase were assayed from $\mathrm{pH}$-controlled cultures. Interestingly, avicelase and $\beta$-glucosidase showed similar profiles, with maximal activity in the $\mathrm{pH}$ 5.5- and 6.0-controlled cultures. The CMCase activity was the highest in the $\mathrm{pH} 4$ controlled culture. The $\mathrm{pH}$ 6.0-controlled culture showed the highest cellulase activity among the cultures grown from $\mathrm{pH} 3.5$ to 6.5 .

The ratio of CMCase and avicelase to cellulase activity was high in the acidic $\mathrm{pH}$ region, but the ratio of $\beta$-glucosidase activity was high in the neutral $\mathrm{pH}$ region. This indicates that the breakage of the internal bond of cellulose and the cleavage of two to four units from the ends of the exposed chains are effective at an acidic $\mathrm{pH}$. However, the hydrolysis of the cellobiose into individual monosaccharides, such as glucose or other reducing sugars, is more efficient at a neutral $\mathrm{pH}$. The effectiveness of the cellulase performance was determined by the synergistic combination of these three enzymes. Therefore, if the 
breaking and cleaving reactions of cellulose are performed at an acidic $\mathrm{pH}$, but the hydrolytic reaction to produce the monosaccharide is accomplished at a neutral $\mathrm{pH}$, then the saccharification yield may be improved. These results indicated that these three types of cellulolytic enzymes are responsive to the culture $\mathrm{pH}$. This is the first report describing the $\mathrm{pH}$ responses of these three types of enzymes on the cellulase production from $A$. cellulolyticus.

We plan to convert the reducing sugars obtained from the saccharification of waste biomass into biomass ethanol. Due to environmental concerns, there is demand for alternative resources, and this study is a step toward the establishment of an efficient system for reutilizing cellulolytic biomass.

Open Access This article is distributed under the terms of the Creative Commons Attribution Noncommercial License which permits any noncommercial use, distribution, and reproduction in any medium, provided the original author(s) and source are credited.

\section{References}

1. Ikeda, Y., Park, E., \& Okuda, N. (2006). Bioresource Technology, 97, 1030-1035.

2. Kádár, Z., Szengyel, Z., \& Réczey, K. (2004). Journal of Biological Chemistry, 153, 375-380.

3. Park, E., Pham, A., \& Okuda, N. (2004). Bioresource Technology, 93, 77-83.

4. Montane, D., Farriol, X., Salvado, J., Jollez, P., \& Chornet, E. (1998). Biomass and Bioenergy, 14, 261276.

5. Tengborg, C., Galbe, M., \& Zacchi, G. (2001). Biotechnology Progress, 17, 110-117.

6. Abbi, M., Kuhad, R. C., \& Singh, A. (1996). Process Biochemistry, 31, 555-560.

7. Vlasenko, E. Y., Ding, H., Labavitch, J. M., \& Shoemaker, S. P. (1997). Bioresource Technology, 59, $109-119$.

8. Palmarola-Adrados, B., Juhasz, T., Galbe, M., \& Zacchi, G. (2004). Biotechnology Progress, 20, 474479.

9. Yamanobe, T., Mitsuishi, Y., \& Takasaki, Y. (1987). Agricultural Biological Chemistry, 51, 65-74.

10. Kansarn, S., Matsushita, N., Kono, T., \& Okada, G. (2000). Journal of Applied Glycoscience, 47, 177185.

11. Park, E., Ikeda, Y., \& Okuda, N. (2002). Biotechnology Bioprocess Engineering, 7, 268-274.

12. Yamanobe, T., Mitsuishi, Y., \& Yagisawa, M. (1988). Agricultural Biological Chemistry, 52, 2493-2501.

13. Yamanobe, T., Hiraishi, J., \& Kruus, I. (1990). Agricultural Biological Chemistry, 54, 535-536.

14. Yamanobe, T., \& Mitsuishi, Y. (1990). Agricultural Biological Chemistry, 54, 301-307.

15. Ikeda, Y., Hayashi, H., Okuda, N., \& Park, E. Y. (2007). Biotechnology Progress, 23, 333-338.

16. Park, E., Michinaka, A., \& Okuda, N. (2001). Biotechnology Progress, 17, 379-382.

17. Sosulski, K., \& Swerhone, B. (1993). US DOE Report NREL-CP-200-5768, 2, 1032-1044.

18. Söderström, J., Pilcher, L., \& Zacchi, G. (2003). Biomass and Bioenergy, 24, 475-486.

19. Ghose, T. K. (1987). Pure \& Applied Chemistry, 59, 257-268.

20. Nelson, N. (1944). Journal of Biological Chemistry, 153, 375-380.

21. Bernfeld, P. (1955). Methods in Enzymology, 1, 149.

22. Domingues, F., Queiroz, J., Cabral, J., \& Fonseca, L. (2000). Enzyme Microbial Technolology, 26, $394-401$.

23. Mountenecourt, B., \& Eveleigh, D. (1979). Advances in Chemistry Series, 181, 289-301.

24. Gáspár, M., Juhász, T., Szemgyl, Z., \& Réczey, K. (2005). Process Biochemistry, 40, 1183-1188.

25. Mandels, M., Weber, J., \& Parizek, R. (1971). Applied Microbiology, 21, 152-154.

26. Chahal, P., Chahal, D., \& Lê, G. (1996). Applied Biochemistry. Biotechnology, 57(58), 433-442.

27. Chen, S., \& Wayman, M. (1991). Process Biochemistry, 26, 93-100.

28. Wen, Z., Liao, W., \& Chen, S. (2005). Bioresource Technology, 96, 491-499.

29. Wen, Z., Liao, W., \& Chen, S. (2005). Process Biochemistry, 40, 3087-3094.

30. Jørgensen, H., \& Olsson, L. (2006). Enzyme and Microbial Technology, 38, 381-390.

31. Adsul, M., Ghule, J., Singh, R., Shaikh, H., Bastawde, K., Gokhale, D., et al. (2004). Carbohydrate Polymers, 57, 67-72. 